\title{
Effect of Rhizobacterial-Mediated Auxin on Growth Promotion of Wheat and Mung Bean Plant
}

\author{
Farzana Iftikhar*, Atia Iqbal \\ Department of Microbiology and Molecular Genetics, The Women University, Multan, Pakistan
}

Received: 17 December 2017

Accepted: 28 February 2018

\begin{abstract}
The use of beneficial rhizobacteria as biofertilizers are best alternatives of chemical fertilizers and might be potential tools for sustainable agriculture. Plant growth promoting rhizobacteria (PGPR) increased crop production by using different mechanisms. Auxin, bacterial phytohormone, plays a significant role in cell elongation, cell division and cell differentiation of plants. The aim of our study was to investigate the native valuable rhizobacteria for growth promotion of wheat and Mung bean plants. The bacterial isolates from different regions of southern Punjab were screened on the basis of their auxin production potential. The auxin production ability was found to be up to $152 \mathrm{ug} / \mathrm{ml}$. Out of 40 strains, $58.8 \%$ were gram-positive rods and the rest were gram negative. All the strains were evaluated for their plant growth-promoting potential while being applied on wheat and Mung bean plants, and observed their effect on plant growth promotion under laboratory conditions. These strains showed significant increases $(\mathrm{p}=0.05)$ in root length, shoot length, dry and fresh weight of wheat and mung bean seedlings as compared to control. Our results indicated that PGPR are the best alternatives of chemical fertilizers and have more capability to increase plant growth and yield. It is a cheaper way to accomplish the increasing demand for food.
\end{abstract}

Keywords: phytohormones, rhizososphere, PGPR; wheat, mung been, rhizobacteria, biofertilizer

\section{Introduction}

Rhizospheric bacteria present in the soil surrounding plant roots have the property to interact with plant roots and ultimately involve plant development beneficially. Due to their plant growth enhancing capacities, these bacteria are called plant growth-promoting rhizobacteria (PGPR) [1]. PGPR effect plant growth

*e-mail: farzanaiftikhar26@gmail.com promotion directly or maybe indirectly [2]. During PGPR-induced biosynthesis of plant growth regulators, different phytohormones such as auxins, abscisic acid, cytokinin, ethylene and gibberellins are produced. The most quantitatively important phytohormone is auxin — especially indole acetic acid (IAA) produced by PGPR [3]. IAA can stimulate seed germination and strengthen the rate of development of xylem and roots and assist the biosynthesis of a variety of plant metabolites [4]. About $80 \%$ rhizobacteria isolated from the rhizospheric soil produce IAA and indole-3acetic acid [5]. IAA biosynthetic pathways in bacteria 
Table 1. Isolation, gram staining and auxin detection of auxin-producing rhizobacteria from soil samples collected from southern Punjab.

\begin{tabular}{|c|c|c|c|c|c|c|c|}
\hline $\begin{array}{l}\text { Sr. } \\
\text { No. }\end{array}$ & $\begin{array}{l}\text { Sample } \\
\text { Area }\end{array}$ & Plant & $\begin{array}{c}\text { Soil } \\
\text { source }\end{array}$ & $\begin{array}{c}\text { No of } \\
\text { Auxin producing bacterial strains }\end{array}$ & $\begin{array}{c}\text { Gram } \\
\text { Staining }\end{array}$ & $\begin{array}{c}\text { Spore } \\
\text { Staining }\end{array}$ & $\begin{array}{c}\text { Auxin Production } \\
\text { (ug/ml) }\end{array}$ \\
\hline \multirow{14}{*}{1} & \multirow{14}{*}{$\begin{array}{l}\text { MLTN } \\
\text { Multan }\end{array}$} & \multirow{14}{*}{$\begin{array}{l}\text { Oriza } \\
\text { sativa }\end{array}$} & \multirow{14}{*}{$\begin{array}{l}\text { Agricul- } \\
\text { ture }\end{array}$} & control & Pink & - & \\
\hline & & & & Wumf1 & Pink & - & 60 \\
\hline & & & & WUM2 & Pink & - & 103 \\
\hline & & & & wumf3 & Pink & - & 48 \\
\hline & & & & wumf4 & Purple & - & 0.78 \\
\hline & & & & wumf5 & Pink & + & 37 \\
\hline & & & & wumf6 & Purple & + & 62 \\
\hline & & & & wumf7 & Purple & + & 85 \\
\hline & & & & wumf8 & Pink & + & 1.5 \\
\hline & & & & wumf9 & Pink & + & 1.8 \\
\hline & & & & wumf10 & Pink & - & 36 \\
\hline & & & & wumf11 & Pink & - & 1.1 \\
\hline & & & & wumf12 & Pink & - & 89 \\
\hline & & & & wumf13 & Purple & - & 58 \\
\hline \multirow{10}{*}{2} & \multirow{10}{*}{$\begin{array}{l}\text { SJB } \\
\text { Shu- } \\
\text { jabad }\end{array}$} & \multirow{10}{*}{$\begin{array}{l}\text { Rosa da- } \\
\text { mascena }\end{array}$} & \multirow{10}{*}{$\begin{array}{l}\text { Non cul- } \\
\text { tivated }\end{array}$} & wumf15 & Purple & + & 0.078 \\
\hline & & & & wumf16 & Pink & - & 58 \\
\hline & & & & wumf17 & Purple & + & 37 \\
\hline & & & & wumf18 & purple & - & 2 \\
\hline & & & & wumf19 & Purple & + & 14 \\
\hline & & & & wumf20 & Pink & - & 92 \\
\hline & & & & wumf21 & Purple & - & 152 \\
\hline & & & & wumf22 & Purple & - & 0.153 \\
\hline & & & & wumf23 & Pink & - & 95 \\
\hline & & & & wumf24 & Pink & - & 0.34 \\
\hline \multirow{6}{*}{3} & \multirow{6}{*}{$\begin{array}{c}\text { JLP } \\
\text { Jalalpur }\end{array}$} & \multirow{6}{*}{$\begin{array}{l}\text { Lycop- } \\
\text { ersicon } \\
\text { esculen- } \\
\text { tum }\end{array}$} & \multirow{6}{*}{$\begin{array}{l}\text { Agricul- } \\
\text { ture }\end{array}$} & wumf25 & Pink & + & 78 \\
\hline & & & & wumf 26 & Pink & - & 0.67 \\
\hline & & & & wumf27 & Pink & + & 105 \\
\hline & & & & wumf28 & Pink & - & 89 \\
\hline & & & & wumf29 & Pink & - & 35 \\
\hline & & & & wumf30 & Pink & - & 80 \\
\hline \multirow{10}{*}{4} & \multirow{10}{*}{$\begin{array}{c}\text { BWP } \\
\text { Bha- } \\
\text { walpur }\end{array}$} & \multirow{10}{*}{ Zea mays } & \multirow{10}{*}{$\begin{array}{l}\text { Agricul- } \\
\text { ture }\end{array}$} & wumf31 & Pink & + & 85 \\
\hline & & & & wumf32 & Purple & - & 35 \\
\hline & & & & wumf33 & Pink & - & 78 \\
\hline & & & & wumf34 & Pink & - & 107 \\
\hline & & & & wumf35 & Purple & - & 110 \\
\hline & & & & wumf36 & Purple & - & 55 \\
\hline & & & & wumf37 & Purple & - & 45 \\
\hline & & & & wumf38 & Pink & - & 0.059 \\
\hline & & & & wumf39 & Pink & - & 98 \\
\hline & & & & wumf40 & Purple & - & 78 \\
\hline
\end{tabular}


and plants are normally similar [6], with tryptophan recognized as a main precursor for IAA biosynthetic pathways in bacteria [7]. Five different pathways have been identified in bacteria that use tryptophan as a main precursor of IAA synthesis: indole-3-acetonitrile pathway, indole-3-pyruvate pathway, indole-3-acetamide pathway, tryptamine pathway, and tryptophan sidechain oxidase pathway [6].

For efficient selection and screening of most promising plant growth promoting rhizobacteria, the isolated strains are significantly characterized biochemically and morphologically [8]. This selection helps to sustain database progress of the microbes, which is essential for plant growth promotion and can be auxiliary used as bio fertilizers [9]. The interest of using biofertilizers in crops instead of chemical fertilizers has developed many folds in recent years [10]. Due to the tremendous increase in world population and increasing demand for food, chemical fertilizers are used significantly in agricultural set ups to enhance productivity and yield of crops that are dangerous to health [11]. The aim of this research was to isolate and characterize the beneficial rhizobacteria from southern Punjab soil and their use as biofertilizers, which can be the best alternatives of chemical fertilizers on wheat and mung bean plant to enhance crop production to fulfill the day-to-day increasing demand for food.

\section{Materials and Methods}

Four different cities of southern Punjab (Multan, Bahawalpur, Shujabad and Jalalpur) were selected for soil sampling. Rhizospheric soil samples were collected, brought to the lab and stored at $4^{\circ} \mathrm{C}$. All strains were screened for auxin production (with the amendment of $1000 \mu \mathrm{g} / \mathrm{ml}$ tryptophan) by Salkowski's method. The experiment was done in triplicates. 40 strains were selected on the basis of maximum auxin production ability (more than $150 \mu \mathrm{g} / \mathrm{ml}$ ) indicated by a deep pink color with Salkowski's reagent. The selected strains were characterized biochemically according to Bergey's Manual of Bacteriology. The ability of selected bacterial strains to grow at different temperatures and $\mathrm{pH}$ was determined at $28^{\circ} \mathrm{C}, 37^{\circ} \mathrm{C}$ and $45^{\circ} \mathrm{C}$ and at $\mathrm{pH} 6.5,7.5$ and 8.5.

For determining IAA produced by rhizobacterial strains, the method described by $[12,13]$ was adopted. Certified Seeds of Triticum aestivum and Vigna radiata were taken from the Punjab Seed Corporation, Multan, Pakistan and were sterilized with $0.1 \% \mathrm{HgCl}_{2}$. Pellets were obtained by growing bacteria in L-broth, washed with $1 \mathrm{ml}$ of phosphate buffer and seeds were soaked in different bacterial suspensions separately for 30 minutes. After bacterial treatment, the seeds were sown at the depth of $2-3 \mathrm{~cm}$ in autoclaved soil
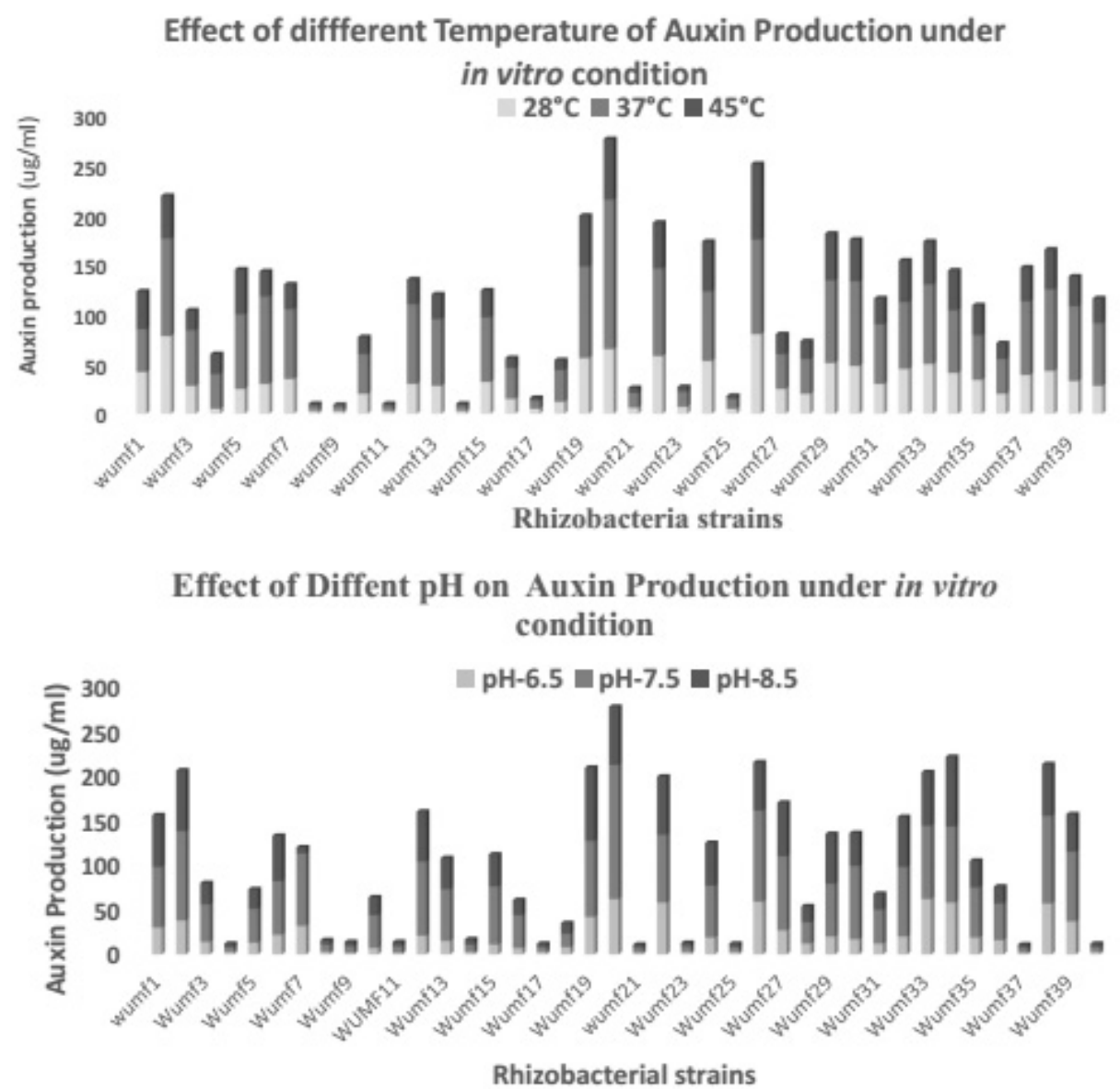

Fig. 1. Effect of physical parameters (temperature and $\mathrm{pH}$ ) on auxin production of rhizobacterial strains under in vitro condition. 
(200 grams) in plastic pots. The percentage of germination was calculated in control and treated plants soon after germination. After 15 days plant seedlings were wiped out carefully, and different growth parameters like root length, shoot length, plant fresh weight and dry weight were measured. The experiment was performed three times to check the validity of the results.

\section{Results}

After initial screening, 20 (WUMF-1, WUMF-2, WUMF-3, WUMF-4, WUMF-5, WUMF-6, WUMF7, WUMF-8, WUMF-9, and WUMF-10 WUMF-11, WUMF-12, WUMF-13, WUMF-14, WUMF-15, WUMF 16, WUMF-17,WUMF-18, WUMF-19, and WUMF-20) strains were selected on the basis of auxin production ability indicated by deep pink color with Salkowski's reagent.

The selected strain showed auxin production potential ranging from $0.059 \mu \mathrm{g} / \mathrm{ml}$ (WUMF 37) to $152 \mu \mathrm{g} / \mathrm{ml}$ (WUMF 20). The maxium auxin production was found in WUMF 20 followed by WUMF34 (110 $\mu \mathrm{g} / \mathrm{ml})$, WUMF33 (107 $\mu \mathrm{g} / \mathrm{ml})$, WUMF26 (105 $\mu \mathrm{g} / \mathrm{ml})$ and WUMF2 $(103 \mu \mathrm{g} / \mathrm{ml})$ respectively. Other strains WUMF6, WUMF7, WUMF12, WUMF13, WUMF15, WUMF19, WUMF22, WUMF24, WUMF27, WUMF29, WUMF32, WUMF35, WUMF38, and WUMF39, produced auxin ranging from 50 to $100 \mu \mathrm{g} / \mathrm{ml}$. Almost all strains showed maxium auxin production at $\mathrm{pH} 7.5$ and temperature at $37^{\circ} \mathrm{C}$ (Fig. 1).

The strains WUMF-6 and WUMF-17 showed significant effect $(p=0.05)$ on wheat root length, whereas all strains showed a significant increase $(\mathrm{p}=0.05)$ in root length of mung bean plants as compared to control (Table 2). The wheat shoot length was significantly enhanced by WUMF-6, WUMF12, WUMF-16, WUMF-17 and WUMF-19, wheras all strains significantly enhance the shoot length of mung bean seedlings (Table 2).

\section{Discussion}

The rhizobacterial strains can enhance growth and yield of economically important crops that are a major source of income for developing countries. Rhizobacteria have a significant role in the growth and development of plants in natural ecosystems [5]. On the other hand, wheat and legumes are extensively using edible crops. Due to the daily increasing world population, there is the necessity to boost food production to meet the increasing demand of food. The study was planned to discover the indigenous useful rhizobacteria present in agricultural soil in order to analyze their utility in growth promotion of wheat and mung bean plants. Primarily, 20 strains were screened out for auxin production potential (WUMF-1-WUMF-20) on the basis of color development with Salkowski's reagent. Maximum auxin-producing selected strains were further biochemically characterized as done by Iqbal and Hasnain [14]. PGPR initiates the developmental changes in plants by eliciting the signaling pathways. Bacterial phytohormones are the main thing for initiating the signaling pathways in plants [15]. Our work has accordance to [12] and [16], who isolated the auxinproducing rhizobacteria for their further consumption in plant growth experiments. The rhizobacterial auxin was investigated for their positive role on Triticum aestivum and Vigna radiata plant growth promotion in laboratory conditions. The root length of Triticum aestivum has been influenced beneficially (59\%) by rhizobacterial auxin. Initiation in root proliferation by bacterial auxin has been investigated by [17], who found that auxinproducing rhizobacteria may give an advantage to plants with regard to its health by absorbing an abundance of nutrients. At early stages of their development young

Table 2. Effect of inoculation of rhizobacterial strains on the growth parameters of Triticum aestivum and Vigna radiata in laboratory conditions.

\begin{tabular}{|c|c|c|c|c|c|c|c|c|}
\hline \multirow{2}{*}{ Strain } & \multicolumn{2}{|c|}{ Root length } & \multicolumn{2}{c|}{ Shoot length } & \multicolumn{2}{c|}{ Dry weight } & \multicolumn{2}{c|}{ Fresh weight } \\
\cline { 2 - 9 } & Wheat & Mung been & Wheat & Mung been & Wheat & Mung been & Wheat & Mung been \\
\hline Control & $8 \pm 1.09$ & $8 \pm 0.09$ & $15 \pm 0.67$ & $10.5 \pm 0.58$ & $355 \pm 48$ & $157 \pm 0.008$ & $1967 \pm 0.009$ & $1055 \pm 0.78$ \\
\hline Wumf-3 & $6 \pm 0.24$ & $16 \pm 0.46$ & $12 \pm 0.78$ & $18 \pm 0.39$ & $114 \pm 38$ & $293 \pm 0.78$ & $1563 \pm 0.19$ & $1467 \pm 0.37$ \\
\hline Wumf-6 & $9 \pm 0.16$ & $12 \pm 1.90$ & $16 \pm 0.76$ & $18 \pm 0.49$ & $703 \pm 98$ & $213 \pm 0.45$ & $2437 \pm 0.067$ & $1435 \pm 0.12$ \\
\hline Wumf-11 & $5 \pm 0.19$ & $16 \pm 1.8$ & $12 \pm 2.09$ & $19 \pm 0.86$ & $773 \pm .47$ & $209 \pm 0.34$ & $2367 \pm 0.78$ & $1434 \pm 0.18$ \\
\hline Wumf-12 & $8 \pm 0.65$ & $12 \pm 0.67$ & $16 \pm 0.67$ & $15 \pm 1.89$ & $854 \pm .27$ & $140 \pm 0.67$ & $2590 \pm 0.28$ & $1489 \pm 0.87$ \\
\hline Wumf-16 & $6 \pm 1.34$ & $12 \pm 0.67$ & $22.5 \pm 0.89$ & $17 \pm 0.86$ & $937 \pm 1.9$ & $189 \pm 0.87$ & $2335 \pm 2.09$ & $1306 \pm 0.65$ \\
\hline Wumf17 & $12 \pm 0.67$ & $20 \pm 0.56$ & $23 \pm 0.76$ & $21.5 \pm 0.67$ & $561 \pm 0.67$ & $222 \pm 0.09$ & $217 \pm 1.09$ & $1107 \pm 0.98$ \\
\hline Wumf-19 & $7 \pm 0.67$ & $13 \pm 0.23$ & $16 \pm 0.87$ & $15 \pm 0.29$ & $934 \pm 0.89$ & $202 \pm 0.89$ & $2610 \pm 0.23$ & $1405 \pm 0.34$ \\
\hline Wumf-20 & $8.5 \pm 1.20$ & $21 \pm 0.78$ & $8.5 \pm 0.56$ & $23 \pm 0.67$ & $983 \pm 0.45$ & $145 \pm 0.12$ & $2506 \pm 0.56$ & $1067 \pm 0.65$ \\
\hline
\end{tabular}


seedlings also played an important role in their survival $[1,18]$. PGPRs are the cheaper and non-toxic tools for better agricultural development; this work can conclude different beneficial bacteria found in soil around plant roots interacting with bacteria for plant growth promotion and increasing fertility of soil.

\section{Conflict of Interest}

The authors declare no conflict of interest.

\section{References}

1. NEHRA V., CHOUDHARY M. A review on plant growth promoting rhizobacteria acting as bioinoculants and their biological approach towards the production of sustainable agriculture. J. Appl. \& Nat. Sci. 7, 540, 2015.

2. GLICK B.R. Bacteria with ACC deaminase can promote plant growth and help to feed the world. Microbiol. Res. 169, 30, 2014.

3. NANDAL M., HOODA R. Plant growth promoting rhizobacteria: a review article. IJCR. 12, 3863, 2013.

4. GAMALERO E., GLICK B.R. Mechanisms used by plant growth-promoting bacteria. In "Bacteria in Agrobiology: Plant Nutrient Management” Springer. 17, 46, 2011.

5. AHEMAD M., KIBRET M. Mechanisms and applications of plant growth promoting rhizobacteria. current perspective. J. King. Sau. Univ. Sci. 26, 1, 2014.

6. SPAEPEN S., VANDERLEYDEN J., REMANS R. Indole-3-acetic acid in microbial and microorganism-plant signaling. FEMS. Microbiol. Rev. 4, 425, 2007.

7. ZAIDI A., KHAN M.S., AHEMAD M., OVES M. Plant grows promotion by phosphate solubilizing bacteria. Acta. Microbiol. Immunol. Hung. 56, 263, 2009.

8. NELSON L.M. Plant growth promoting rhizobacteria (PGPR):Prospects for new inoculants. Online. Crop Management, 2004.

9. KHAKIPOUR N., KHAVAZI K., PAZIRA E., ASADIRAHMANI H. Production of Auxin Hormone by Fluorescent Pseudomonads. American-Eurasian J. Agric. \& Environ. Sci. 4, 687, 2008.
10. A SHOEBITZ M., RIBAUDO C.M., PARDO M.A., CANTORE M.L., CIAMPI L., CURA J.A. Plant growth promoting properties of a strain of Enterobacter ludwigii isolated from Lolium perennerhizosphere. Soil. Biol. Biochem. 41, 1768, 2009.

11. ZIZ K., NAWAZ M., NAZIR J., ANJUM A.A., YAQUB T., AHMAD D.U.M., REHAN U.M., AZIZ G., KHAN M. Isolation, characterization and effect of auxin producing bacteria on growth of triticum aestivum. J. Anim. Plant. Sci. 25, 1003,2015.

12. ALI B., SABRI N.A., LJUNG K., HASNAIN S. Quantification of indole-3-acetic acid from plant associated Bacillus spp. and their phytostimulatory effect on Vigna radiata (L.). World. J. Microbiol. Biotechnol. 25, 519, 2009.

13. SARWAR M.A., IBRAHIM M., TAHIR M., AHMAD K., KHAN Z.I., VALEEM E.E. Appraisal of pressmud and inorganic fertilizers on soil properties, yield and sugarcane quality. Pak. J. Bot. 42, 1361, 2010.

14. IQBAL A., HASNAIN S. Auxin Producing Pseudomonas Strains: Biological Candidates to Modulate the Growth of Triticum aestivum Beneficially. Am. J. Plant. Sci, 4, 1693, 2013.

15. CASSÁN F, VANDERLEYDEN J., SPAEPEN S. Physiological and agronomical aspects of phytohormone production by model plant-growth-promoting rhizobacteria (PGPR) Belonging to the Genus Azospirillum. J. Plant. Growth. Regul. 33, 440, 2014.

16. HUSSAIN A., HASNAIN S. Interactions of bacterial cytokinins and IAA in the rhizosphere may alter phytostimulatory efficiency of rhizobacteria. World. J. Microbiol. Biotechnol. 27, 2645, 2011.

17. MINAX I., SAXENA J. Disease suppression and crop improvement in moong beans (Vigna radiata) through Pseudomonas and Burkholderi as trains isolated from semi arid region of Rajasthan, India. Bio.Cont. 55, 799, 2010.

18. VASUDEVAN P., REDDY S.M., KAVITHA S., VELUSAMY P., PAULRA J., DAVID S.R., PURUSHOTHAMAN M.S., PRIYADARSIN I. BRINDHA V., BHARATHKUMAR S., KLOEPPER W.J., GNANAMANICKAM S.S. Role of biological preparations in enhancement of rice seedling growth and grain yield. Current Science, 83, 1140, 2002. 